\title{
Assessment of invasion frequencies of cultured HEp-2 cells by clinical isolates of Helicobacter pylori using an acridine orange assay
}

\author{
S M Wilkinson, J R Uhl, B C Kline, F R Cockerill III
}

\begin{abstract}
Aims-Recent studies suggest that Helicobacter pylori is an invasive enteropathogen. However, the efficiency with which this pathogen invades mammalian cells remains unknown. Therefore, this study was designed to investigate the invasion frequencies of HEp-2 cells by clinical strains of $H$ pylori.

Methods-An acridine orange assay and cultured HEp-2 cell monolayers were used to determine the $\mathrm{HEp}-2$ cell penetration frequencies of 17 clinical isolates and one American Type Culture Collection (ATCC) strain of $\boldsymbol{H}$ pylori, and single clinical strains of Yersinia enterocolitica, Shigella flexneri, and a non-invasive ATCC Escherichia coli strain.

Results-The acridine orange assay demonstrated that invasion frequencies of HEp-2 cells by all $H$ pylori isolates were significant and, in most instances, exceeded those for the $S$ flexneri strain and equalled those for the $Y$ enterocolitica strain. The assay also showed that internalised $H$ pylori organisms remained viable for at least six hours, the maximum time that bacteria and HEp-2 cells were co-incubated.
\end{abstract}

Conclusions-These results may have important implications for treatment and prevention strategies for this gastric pathogen. Furthermore, the acridine orange assay may be useful for assessing, in vitro, the ability of conventional and newer antibiotics, alone or in combination, to kill intracellular $H$ pylori organisms.

(f Clin Pathol 1998;51:127-133)

Keywords: Helicobacter pylori; internalisation; ulcer disease

In general, Helicobacter pylori is not considered to be an invasive enteropathogen. However, some investigators, using either light or electron microscopy, have observed $H$ pylori microorganisms in the lower corpus mucosa of gastric tissue and in the cytoplasm of gastric epithelial cells from humans with chronic gastritis or gastric metaplasia. ${ }^{1-9}$ Recently, one in vitro study by Evans and colleagues ${ }^{1}$ demonstrated the ability of $H$ pylori to enter cultured HEp-2 cells. For this study, the level of internalisation was determined by a conventional gentamicin internalisation assay. In this assay, extracellular bacteria are killed by high levels of gentamicin. Intracellular (internal- ised) bacteria are protected from gentamicin, because this antibiotic cannot permeate living mammalian cells. Mammalian cells are then lysed, and the released intracellular bacteria are counted on plate cultures.

Using the gentamicin internalisation assay, Evans and colleagues showed that the level of $H$ pylori internalisation was $\sim 0.1 \%$ of the inoculum $\left(10^{4}\right.$ bacteria per $2 \times 10^{5} \mathrm{HEp}-2$ cells). This would appear to be significant because similar percentages have been determined for Shigella spp by the same method. However, these investigators did not measure the number of HEp-2 cells that contained internalised, live $H$ pylori organisms. Such an analysis may have greater clinical relevance and permit comparison studies of the ability of $H$ pylori to enter mammalian cells with other highly invasive enteropathogens such as Yersinia enterocolitica. Furthermore, for such a comparison, an analysis of the number of HEp-2 cells infected with viable, internalised $H$ pylori, instead of simply the percentage of $H$ pylori inoculum internalised, might also be more meaningful. This is because growth requirements (media, incubation, and conditions) vary considerably between $H$ pylori and other invasive enteropathogens such as Shigella spp, Salmonella spp, and Yersinia spp. In fact, some viable, internalised $H$ pylori grow very slowly at first, because they are in a temporary, dormant state $^{89}$ and, therefore, might not be detected with gentamicin internalisation assays.

The main objective of the current study was to determine the ability of 17 clinical isolates and one reference strain of $H$ pylori, and single strains of $Y$ enterocolitica (a highly invasive microorganism), $S$ flexneri (a relatively less invasive microorganism), and Escherichia coli (a non-invasive strain) to enter cultured HEp-2 cells. Multiple isolates of $H$ pylori were studied in an attempt to determine whether certain clinical conditions were more often associated with invasion. We also wanted to determine whether internalised $H$ pylori organisms were viable. To accomplish these objectives, an in vitro acridine orange ${ }^{10}$ assay was used. In this assay, acridine orange stains all bacteria under fluorescent light microscopy. Viable microorganisms produce green fluorescence; nonviable organisms produce red fluorescence. The change in colour is attributed to an increase in acridine orange interchelating with the phosphate-sugar backbone of DNA as the DNA becomes denatured in non-viable cells. ${ }^{11}{ }^{12}$ To determine whether microorganisms
Accepted for publication 11 November 1997 
are internalised by epithelial cells, a crystal violet counterstain is applied that effectively quenches the fluorescence of extracellular bacteria. Subsequently, only fluorescent intracellular bacteria are observed under fluorescent light microscopy. ${ }^{10}$ Using this assay, we found the $H$ pylori isolates to be significantly invasive, with HEp-2 cell invasion frequencies comparable to the $Y$ enterocolitica isolate also studied. We also found that virtually all internalised $H$ pylori appeared viable for at least six hours, the maximum time that bacteria and HEp-2 cells were co-incubated.

\section{Materials and methods}

BACTERIAL STRAINS

Eighteen strains of $H$ pylori were investigated. Seventeen were clinical isolates obtained from different patients treated at the Mayo Clinic, and one was American Type Culture Collection (ATCC) strain 43504. Two of the eighteen Mayo Clinic isolates were deposited in the ATCC and their current designations are ATCC 51652 (aka MC903) and ATCC 51653 (aka MC123). Fourteen of the clinical isolates were from patients with gastritis, two were from patients with duodenal ulcer and gastritis, and one was from a patient with an ulcerative carcinoid tumour (table 1). Ten of the 17 clinical strains of $H$ pylori have been evaluated previously for genetic relatedness using the techniques of pulsed field gel electrophoresis of genomic DNA and/or sequencing of $16 \mathrm{~S}$ ribosomal DNA. ${ }^{13}$ These strains included MC004, MC194, MC268, MC443, MC715, MC731, MC937, ATCC 51652, and ATCC 51653. Isolates of $Y$ enterocolitica (FC1), $S$ flexneri (SW1), and a reference, non-invasive $E$ coli strain (ATCC 25922) were also obtained from patients treated at the Mayo Clinic, and studied. The $Y$ enterocolitica and $S$ flexneri isolates were obtained from patients with clinically invasive disease. All bacterial strains were grown on $5 \%$ sheep's blood agar plates at $37^{\circ} \mathrm{C}$ in $5 \% \mathrm{CO}_{2}$ and $95 \%$ humidity for 48 hours. Just before use in the internalisation assay, the bacteria were harvested from the agar plate, washed in Gey's solution and resuspended to $1.5-3 \times 10^{8}$ cells $/ \mathrm{ml}$.

HEp-2 CELL MONOLAYERS

HEp-2 (ATCC CCL 23) cells were grown in basal medium Eagle supplemented with Hank's salts, $50 \mathrm{mM}$ L-glutamine, $0.75 \%$ sodium bicarbonate, and $15 \%$ fetal bovine serum (BME). All bacterial and $\mathrm{HEp}-2$ cell cultures were incubated at $37^{\circ} \mathrm{C}$ in $10 \% \mathrm{CO}_{2}$ and $99 \%$ humidity.

ACRIDINE ORANGE INTERNALISATION ASSAY

HEp-2 cells were trypsinised, washed in BME, and counted. Approximately $1 \times 10^{6}$ cells were placed in each well of a Lab-Tek, eight well, Permanox chamber slide with $100 \mu \mathrm{l}$ of BME and incubated overnight to allow the cells to attach. Aliquots of $100 \mu \mathrm{l}$ bacterial suspension were added to chamber wells of duplicate slides and incubated for three hours. This suspension created an inoculation (high inoculum) of $\sim 150$ bacteria/HEp-2 cell. A lower inoculum, of $\sim 15$ bacteria/HEp-2 cell, was created by diluting the original suspension $1: 10$. S flexneri strain FC1 and Y enterocolitica strain SW 1 were used as positive controls for association (adhering or internalised bacteria, see Microscopy Section) and internalisation, and the $E$ coli ATCC 25922 strain was used as the negative control. After varying incubation times (three to six hours), the chambers were gently washed three times with Hank's balanced salt solution (HBSS) to remove any bacteria not adhering to the HEp-2 cells and the chambers were removed. One slide was Giemsa (Azure B-type) stained and used to determine whether the condition of the monolayer was good enough to continue.

The other slide was stained with acridine orange/crystal violet. Cells on the chamber slides were stained with $0.01 \%$ acridine orange in Gey's solution for 45 seconds at room temperature and washed with HBSS. The cells were then stained with $0.05 \%$ crystal violet in $0.15 \% \mathrm{NaCl}$ for 45 seconds and washed with HBSS. The slides were examined at $40 \times$ magnification, switching between fluorescent and phase contrast optics. In each well, $50 \mathrm{HEp}-2$ cells were examined to determine the number of HEp- 2 cells with associated bacteria (adherent or internalised bacteria, visible by phase contrast microscopy) or internalised bacteria (bacteria visible only by fluorescent microscopy). These analyses were repeated in triplicate for each bacterial isolate and the mean and standard error of the mean were determined.

\section{GENTAMICIN INTERNALISATION ASSAY}

A sample of five of the $H$ pylori isolates (MC013, ATCC 51653, MC207, MC443, and ATCC 51652) were also evaluated in duplicate for internalisation using a standard gentamicin internalisation assay, ${ }^{14}$ with minor modifications. ${ }^{1}$ Briefly, HEp-2 cell monolayers in chamber wells and bacterial suspensions in HBSS were prepared as described above. Bacterial suspensions were inoculated into chamber wells and incubated for three hours. The HBSS containing bacterial chambers were then removed and HEp-2 monolayers were gently washed three times with HBSS. HBSS containing gentamicin $(100 \mu \mathrm{g} / \mathrm{ml})$ was then added to the wells and incubated for one hour to kill extracellular bacteria. Monolayers were then washed six times with HBSS and flooded with poly-L-lysine for five minutes to release intracellular bacteria. Serial 10-fold dilutions of the lysed monolayer were placed on sheep's blood agar to determine the number of viable intracellular bacteria.

\section{ELECTRON MICROSCOPY}

The $H$ pylori ATCC 51652 strain was evaluated for penetration of HEp-2 cells by electron microscopy. Organisms were incubated in $25 \mathrm{~cm}^{2}$ tissue culture flasks (Corning Glassworks Co, Corning, New York, USA) containing confluent HEp-2 cell monolayers. After three hours, cells were washed to remove nonadherent and loosely attached bacteria. The HEp-2 cells were gently scraped off the polystyrene surface with a rubber policeman 
and then suspended in phosphate buffered saline (PBS). Cells were then pelleted and washed in distilled water, and the pellet was fixed in Trump's fixative ( $1 \%$ glutaraldehyde and $4 \%$ formaldehyde in $0.1 \mathrm{M}$ phosphate buffer, $\mathrm{pH} 7.2) .{ }^{15}$ The pellet was then rinsed for 30 minutes in three changes of $0.1 \mathrm{M}$ phosphate buffer, $\mathrm{pH} 7.2$, followed by a one hour postfix in phosphate buffered $1 \% \mathrm{OsO}_{4}$. After rinsing in three changes of distilled water for 30 minutes, the tissue was stained en bloc with $2 \%$ uranyl acetate for 30 minutes at $60^{\circ} \mathrm{C}$. Subsequently, the tissue was rinsed in three changes of distilled water, dehydrated in progressive concentrations of ethanol and $100 \%$ propylene oxide, and embedded in
Spurr's resin. ${ }^{16}$ Thin $(90 \mathrm{~nm})$ sections were cut on a Reichert Ultracut E ultramicrotome, placed on 200 mesh copper grids, and stained with lead citrate. Micrographs were taken on a JEOL 1200 EXII operating at $60 \mathrm{kV}$.

\section{Results}

In table 1 , the percentage of HEp- 2 cells associated with or invaded by each of the bacterial strains is shown. All $H$ pylori strains associated with or penetrated HEp-2 cells to some degree, and the frequency with which HEp-2 cell association or penetration occurred corresponded with the amount of the bacterial inoculum applied to the HEp-2 cell monolayers. Furthermore, all $H$ pylori strains, except

Table 1 Comparison of infected HEp-2 cells stained with acridine orange crystal violet and phase contrast microscopy three hours after infection

\begin{tabular}{|c|c|c|c|c|c|c|}
\hline \multirow[b]{2}{*}{ Strain } & \multirow[b]{2}{*}{ Endoscopic observations } & \multirow[b]{2}{*}{ Histological diagnosis } & \multicolumn{2}{|c|}{$\begin{array}{l}\text { High inoculum } \\
\text { Mean (SEM) \% of cells }\end{array}$} & \multicolumn{2}{|c|}{$\begin{array}{l}\text { Low inoculum } \\
\text { Mean (SEM) \% of cells }\end{array}$} \\
\hline & & & Association & Invasion & Association & Invasion \\
\hline \multicolumn{7}{|l|}{ Helicobacter pylori } \\
\hline MC004 & Normal examination & $\begin{array}{l}\text { Moderately active chronic gastritis } \\
\text { Mild glandular atrophy } \\
\text { Moderate numbers of } H \text { pylori } \\
\text { organisms }\end{array}$ & $97.3(1.10)$ & $32.0(4.16)$ & $72.0(1.16)$ & $42.0(5.30)$ \\
\hline $\mathrm{MC} 013$ & Normal examination & $\begin{array}{l}\text { Moderately active chronic gastritis } \\
\text { Few } H \text { pylori organisms }\end{array}$ & $70.0(7.58)$ & $34.7(5.81)$ & $62.7(3.71)$ & $22.0(13.13)$ \\
\hline ATCC 51653 (aka MC123) & Normal examination & $\begin{array}{l}\text { Moderately active chronic gastritis } \\
\text { Mild glandular atrophy } \\
\text { Many H pylori organisms }\end{array}$ & $89.3(7.86)$ & $41.3(5.70)$ & $83.0(3.00)^{\star}$ & $56.0(2.00)^{\star}$ \\
\hline MC194 & Mild gastritis & $\begin{array}{l}\text { Moderately active chronic gastritis } \\
\text { Moderate glandular atrophy } \\
\text { Moderate numbers of } H \text { pylori } \\
\text { organisms }\end{array}$ & $96.7(2.41)$ & $46.0(4.17)$ & $67.3(4.67)$ & $21.3(0.67)$ \\
\hline MC196 & Mild gastritis & $\begin{array}{l}\text { Moderately active chronic gastritis } \\
\text { No } H \text { pylori organisms visualised }\end{array}$ & 100.0 & $92.0(5.30)$ & $96.0(2.00)^{\star}$ & $88.0(2.00)^{\star}$ \\
\hline MC199 & Large gastric ulcer & $\begin{array}{l}\text { Primary ulcerating carcinoid } \\
\text { tumour of the stomach } \\
\text { Many } H \text { pylori organisms }\end{array}$ & $54.7(4.67)$ & $4.7(1.77)$ & $46.0(5.78)$ & $4.0(1.16)$ \\
\hline MC207 & Generalised gastritis & $\begin{array}{l}\text { Mildly active chronic gastritis } \\
\text { Few } H \text { pylori } \text { organisms }\end{array}$ & $98.7(1.34)$ & $98.7(1.34)$ & $75.0(17.00)$ & $72.0(20.00)$ \\
\hline MC243 & Generalised gastritis & $\begin{array}{l}\text { Mildly active chronic gastritis } \\
\text { Moderate numbers of } H \text { pylori } \\
\text { organisms }\end{array}$ & 100.0 & 100.0 & $91.0(9.00)^{\star}$ & $90.0(10.00)^{\star}$ \\
\hline MC268 & $\begin{array}{l}\text { Prepyloric and } \\
\text { proximal duodenal } \\
\text { bulb deformity, } \\
\text { duodenal ulceration }\end{array}$ & $\begin{array}{l}\text { Severe active chronic gastritis } \\
\text { Duodenal ulceration, mild } \\
\text { glandular hypertrophy } \\
\text { Many } H \text { pylori organisms }\end{array}$ & 100.0 & 100.0 & $94.7(2.67)$ & $72.7(2.41)$ \\
\hline MC443 & Normal examination & $\begin{array}{l}\text { Mildly active chronic gastritis } \\
\text { No } H \text { pylori organisms visualised }\end{array}$ & $99.3(0.67)$ & $94.7(5.03)$ & $97.0(3.00)^{\star}$ & $75.0(15.00)^{\star}$ \\
\hline MC597 & $\begin{array}{l}\text { Moderate fundal } \\
\text { gastritis }\end{array}$ & Not donet & 100.0 & 100.0 & $97.0(3.00)^{\star}$ & $96.0(4.00)^{\star}$ \\
\hline MC658 & $\begin{array}{l}\text { Slightly prominent } \\
\text { fundal fold and slight } \\
\text { antral deformity }\end{array}$ & $\begin{array}{l}\text { Severely active chronic gastritis } \\
\text { Moderate glandular atrophy } \\
\text { Moderate numbers of } H \text { pylori } \\
\text { organisms }\end{array}$ & $97.3(2.67)$ & $83.3(6.57)$ & $41.3(14.64)$ & $31.3(11.86)$ \\
\hline MC715 & Normal examination & $\begin{array}{l}\text { Moderately active chronic gastritis } \\
\text { Many } H \text { pylori organisms }\end{array}$ & $98.0(2.00)$ & $57.3(6.57)$ & $92.0(2.00)$ & $49.3(2.41)$ \\
\hline MC731 & Normal examination & $\begin{array}{l}\text { Moderately active chronic gastritis } \\
\text { Multiple large lymphoid follicles } \\
\text { No } H \text { pylori visualised }\end{array}$ & 100.0 & 100.0 & $89.0(3.00)^{\star}$ & $75.0(7.00)^{\star}$ \\
\hline MC901 & $\begin{array}{l}\text { Patchy erythema } \\
\text { within duodenal bulb }\end{array}$ & $\begin{array}{l}\text { Mildly active chronic gastritis } \\
\text { Mild glandular atrophy } \\
\text { Few } H \text { pylori organisms }\end{array}$ & $98.0(1.16)$ & $91.3(4.38)$ & $85.0(1.00)^{\star}$ & $75.0(7.00)^{\star}$ \\
\hline ATCC 51652 (aka MC903) & $\begin{array}{l}\text { Nodularity of } \\
\text { antrum, slight } \\
\text { erosive changes } \\
\text { in duodenum }\end{array}$ & $\begin{array}{l}\text { Severely active chronic gastritis, } \\
\text { duodenal ulcer } \\
\text { Moderate glandular atrophy } \\
\text { Moderate intestinal metaplasm } \\
\text { Many } H \text { pylori organisms }\end{array}$ & 100.0 & $91.3(4.06)$ & $99.0(1.00)$ & $93.0(3.00)^{\star}$ \\
\hline MC937 & Normal examination & $\begin{array}{l}\text { Moderately active chronic gastritis } \\
\text { Mild glandular hypertrophy } \\
\text { No } H \text { pylori organisms visualised }\end{array}$ & $98.0(1.16)$ & $92.0(0.00)$ & $87.3(2.91)$ & $65.3(8.36)$ \\
\hline Yersinia enterocolitica $\mathrm{FC} 1$ & Not done & Not doneł & $99.3(0.67)$ & $98.7(1.34)$ & $99.3(0.63)$ & $90.7(9.34)$ \\
\hline Shigella flexneri SW 1 & Not done & Not done & $13.3(2.91)$ & $7.3(2.67)$ & $8.7(1.77)$ & $6.0(1.16)$ \\
\hline E coli ATCC 25922 & Not applicable & Not applicable & $2.0(1.00)$ & 0.0 & 0.0 & 0.0 \\
\hline
\end{tabular}

High inoculum refers to $\sim 150$ bacteria per HEp- 2 cell. Low inoculum refers to $\sim 15$ bacteria per HEp- 2 cell

Association, percentage of HEp-2 cells with associated (adherent and internalised) bacteria visible by phase contrast microscopy.

Invasion, percentage of HEp-2 cells with internalised bacteria visible by fluorescent microscopy.

*Evaluation performed in duplicate, all other evaluations performed in triplicate.

†For this patient, biopsies were obtained but were submitted for culture only.

$\$$ This patient had enteritis with recovery of this isolate of $Y$ enterocolitica from the stool

$§$ This patient had dysentery with recovery of this isolate of $S$ flexneri from the stool. 

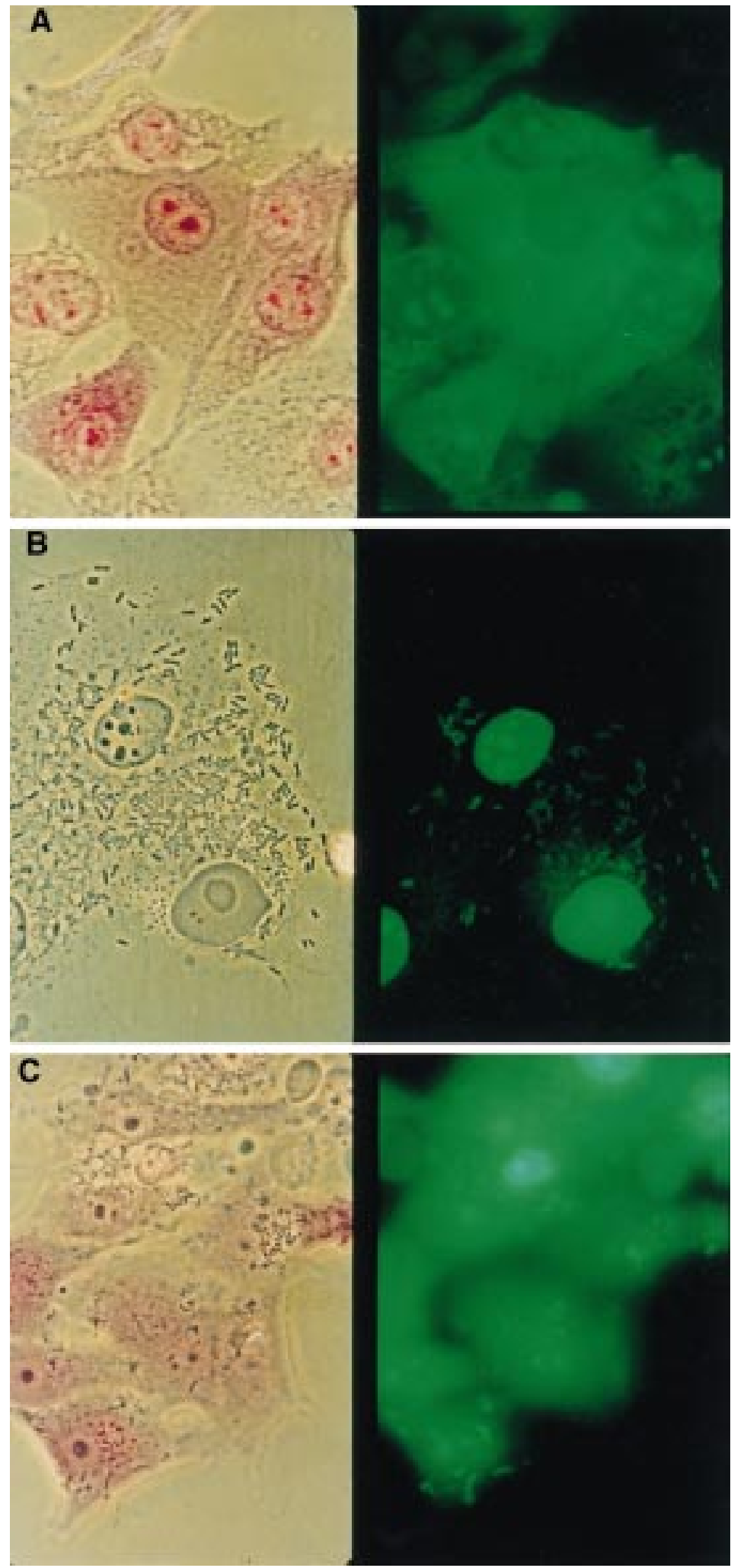

Figure 1 Representative phase contrast and acridine orange photomicrographs of identical microscopic fields of HEp-2 cells co-incubated with bacteria for three hours (original magnifications $\times 500$ ). The phase contrast micrographs show associated bacteria - that is, bacteria adhering to and/or internalised by HEp-2 cells. The corresponding acridine orange micrographs, in all but panel $A$, show green fluorescent bacteria, indicating that they are viable microorganisms internalised by $H E p-2$ cells. (A) Escherichia coli ATCC 25922, high inoculum; no associated or internalised bacteria are present. (B) Yersinia enterocolitica FC1, low inoculum; both associated and viable, internalised bacteria are present. (C) Helicobacter pylori ATCC 51653 (aka MC123), low inoculum; both associated and viable, internalised bacteria are present. one (strain MC199 isolated from a patient with a carcinoid tumour), invaded HEp-2 cells to a greater degree than the $S$ flexneri strain studied. Some $H$ pylori strains, particularly those isolated from patients with ulcerative disease, invaded HEp-2 cells at frequencies similar to the $Y$ enterocolitica strain studied. The $E$ coli strain showed little or no adherence to or penetration of HEp-2 cells.

Figure 1 shows representative phase contrast and acridine orange photomicrographs for the $E$ coli ATCC $25922, Y$ enterocolitica $\mathrm{FC1}$, and $H$ pylori ATCC 51653 and MC013 strains. Except for the $E$ coli MC1 strain, which showed no fluorescent bacteria, all acridine orange assays showed green florescent organisms, indicating viability. Extending incubation times beyond six hours frequently resulted in extensive cytotoxicity of HEp-2 cells and, therefore, stains for $H$ pylori organisms were uninterpretable.

Figure 2 shows photographs of transmission electron microscopy for the $H$ pylori strain ATCC 51652. This strain produced significant clinical disease (severely active chronic gastritis and duodenal ulcer) and invaded $91.3 \%$ of HEp-2 cells when a high inoculum of bacteria was studied (table 1). H pylori organisms are shown that are adherent to or internalised by HEp-2 cells. Internalised organisms were more often coccoid in appearance. In contrast, adherent organisms were more often bacilliform in appearance.

Not shown in table form are the results for gentamicin internalisation assays for the five $H$ pylori strains studied. This assay confirmed that all of these strains invaded HEp-2 cells. The range of internalisation frequencies for $\mathrm{H}$ pylori organisms varied from $0.0006 \%$ (strain MC207) to $0.0019 \%$ (strain MC443) of the inoculum $\left(\sim 10^{8}\right.$ organisms/well).

\section{Discussion}

The results of the acridine orange assay showed that all of the $H$ pylori strains that we evaluated penetrated HEp-2 cells to some degree. We also observed that with this assay nearly all internalised $H$ pylori produced green fluorescence, indicating that these organisms were viable. We rarely observed bacilli that produced red fluorescence, indicating non-viability and, therefore, non-viable microorganisms were not measured. The results for electron microscopy and the gentamicin internalisation assays for the subgroup of $H$ pylori strains that we studied confirmed that $H$ pylori organisms penetrated HEp-2 cells. The gentamicin internalisation assay showed that a lower percentage of the inoculum was internalised compared with that reported by Evans and colleagues. ${ }^{1}$ For our assay and the Evans assay, a similar number of HEp-2 cells were used. However, we exposed the HEp-2 cells to a higher concentration of $H$ pylori organisms, $\sim 10^{8}$ organisms compared with $\sim 10^{7}$ organisms used by Evans and colleagues. It is possible that internalisation frequencies remain static once HEp-2 cells are exposed to a critical concentration of bacteria. Also, in our study, a higher inoculum of bacteria might have resulted in greater HEp- 2 cell 

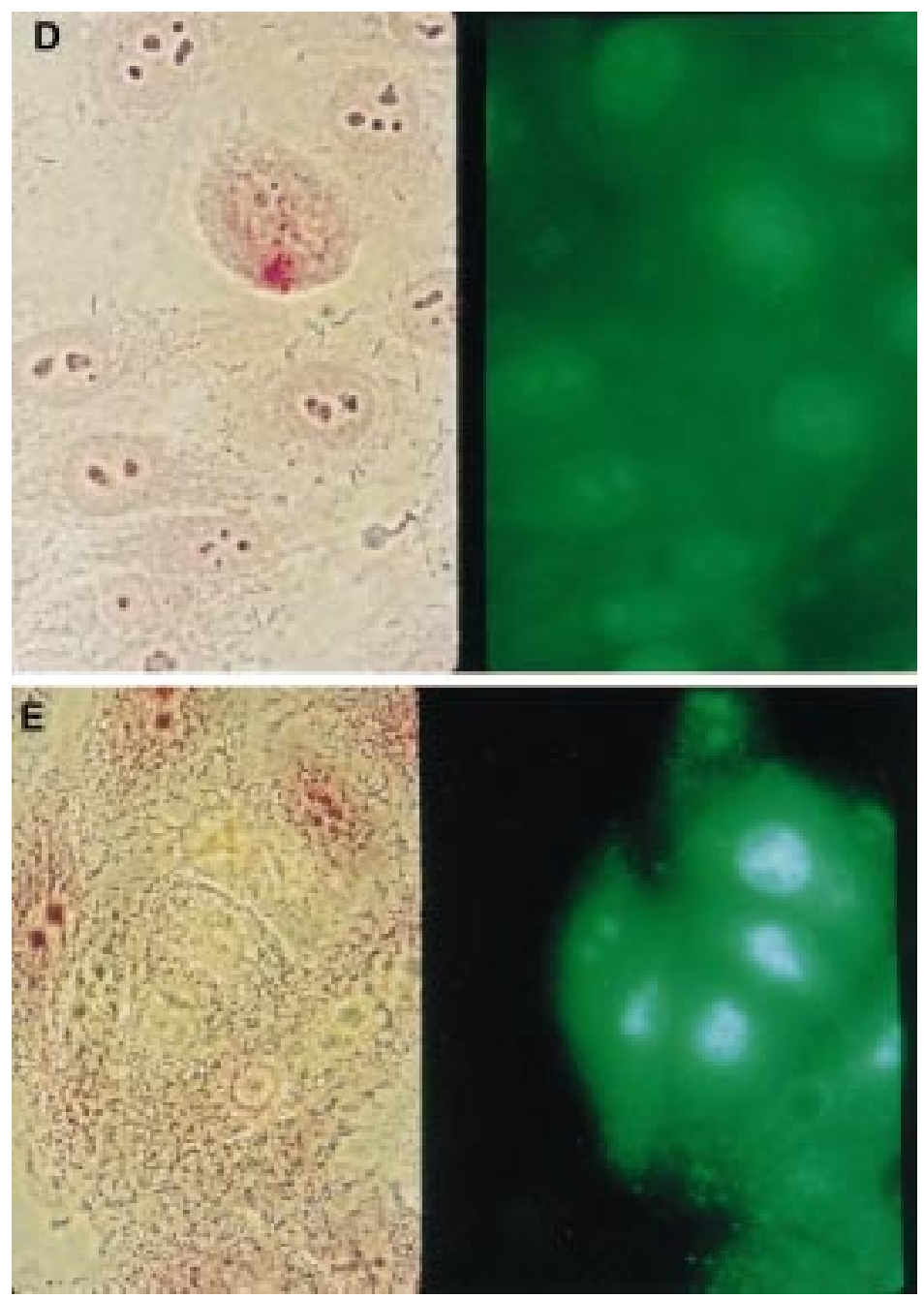

Figure 1 (cont) (D) Helicobacter pylori 013, low inoculum; associated but not internalised bacteria are present. (E) Helicobacter pylori MC004, high inoculum; numerous associated and internalised bacteria are present.

cytotoxicity and lysis, which would expose a higher number of internalised $H$ pylori organisms to the antibiotic effect of gentamicin.

To our knowledge, the current report is the first to describe the frequency with which nonprofessional phagocytes, such as HEp-2 cells, are penetrated by $H$ pylori. The efficient and rapid penetration of HEp-2 cells by many of the $H$ pylori strains that we studied was impressive. HEp-2 penetration frequencies were inoculum dependent, but significant at both high $(\sim 150$ bacteria/HEp-2 cell) and low $(\sim 15$ bacteria/HEp-2 cell) inocula, especially when compared to two other significantly invasive enteropathogens, $S$ flexneri and $Y$ enterocolitica. Bovallius and colleagues reported that approximately $90 \%$ of HeLa cells infected with Y pseudotuberculosis contained internalised bacteria after three hours of incubation. ${ }^{17}$ Devenish and colleagues observed similar results for $Y$ enterocolitica, ${ }^{18}$ which we also found for the $Y$ enterocolitica clinical isolate that we studied. Lower frequencies of mammalian cell penetration by Shigella spp, ${ }^{19}$ compared with Yersinia spp, are reported, which agrees with our results for the $S$ flexneri and $Y$ enterocolitica clinical isolates that we studied. In our evaluation, the
HEp-2 cell penetration frequencies for $H$ pylori strains were considerably greater than those for the $S$ flexneri isolate. In fact, penetration frequencies for some $H$ pylori strains approximated that of the $Y$ enterocolitica clinical isolate.

Although $H$ pylori invasion has been noted in biopsied human tissue, the invasion frequencies of gastric epithelial cells would appear to be less than was observed in vitro. ${ }^{1-9}$ However, comprehensive analyses for invasion frequencies in human gastric tissue have not been performed. This would require careful evaluation of biopsied tissue for internalised $H$ pylori organisms using electron microscopy or an acridine orange assay. Simply evaluating haematoxylin and eosin stains is not sufficient. Even so, these differences, if they are real, may relate to several factors. (1) We may have used higher concentrations of $H$ pylori organisms in our in vitro assay than are normally present in vivo. (2) We evaluated an HEp-2 epithelial cell line and not a human gastric cell line. Differences in $H$ pylori penetration may exist between different epithelial cell lines. (3) Human cell lysis due to $H$ pylori vacA protein may be another factor. As we determined with the in vitro assay, HEp-2 cells that were invaded by $H$ pylori organisms frequently underwent lysis within hours. In the human, $H$ pylori may invade gastric cells and then cause lysis in relatively short time periods so that internalised $H$ pylori can only be observed for critical time periods. (4) Some $H$ pylori organisms in humans may be in a latent or vegetative state and as such may colonise surfaces of epithelial cells but not invade them. That is, log phase growth as produced in vitro may not always occur in vivo.

We did not assess the ability of $H$ pylori to replicate in HEp-2 cells. Such an assessment would have required extended incubation periods. Of note, we encountered significant cytotoxicity of HEp- 2 cells if the incubation period was extended beyond six hours. This cytotoxicity varied with the $H$ pylori strains that we evaluated and might have been the result of vacuolating cytotoxin produced by this organism. This toxin has been well characterised by others $^{20-22}$ and its effects were obvious to us with microscopic evaluation. Creation of isogenic mutants, which do not produce cytotoxin, may permit further study of the ability of $H$ pylori organisms to survive and replicate over extended time periods within non-professional phagocytes, such as HEp-2 cells.

Small and colleagues ${ }^{23}$ co-incubated an enteroinvasive $E$ coli strain and HEp-2 cells for up to six hours. After lysing the HEp-2 cells and plating the internalised bacteria, they showed that these bacteria replicated at a higher frequency than Yersinia spp in HEp-2 cells. Replication was most obvious at incubation periods equal to or exceeding three hours. Similar to our experience with $H$ pylori, incubation periods exceeding six hours were not possible owing to destruction of the HEp-2 monolayer. Sansonetti et al, using a similar approach, showed that maximal replication of $S$ flexneri strains within Hela cells occurred at incubation periods of five hours. ${ }^{19}$ Because of 
the slower growth of $H$ pylori relative to other bacteria, even longer incubation periods for internalised $H$ pylori organisms may be required.

It was difficult for us to determine a direct relation between the extent of disease for each patient, as determined by histopathology of biopsied tissue, and the extent of HEp-2 invasion by the responsible $H$ pylori strain. All $H$ pylori strains except one (MC199) invaded HEp-2 cells with significant frequencies at both low and high inocula. Helicobacter pylori strain MC199 was recovered from a patient with an ulcerating carcinoid tumour. It is possible that this organism was merely colonising the patient's carcinoid lesion. Some strains of $H$ pylori may have inherently more invasive potential, but it is more likely that invasion is related to the expression of invasion associated factors, most likely proteins. Recently, an adhesion associated protein, encoded by the gene hpaA, has been described by Evans and colleagues. ${ }^{24}$ The exact role that the adhesion protein, $\mathrm{HpaA}$, and other $H$ pylori factors play in facilitating mammalian cell invasion, remains unanswered. Clearly, molecular and cellular investigations of the strains evaluated in the current study are required to validate the differences in HEp-2 penetration frequencies that we observed. Previously, we evaluated nine of the $H$ pylori strains used in the current study for genetic relatedness, using the techniques of pulsed field electrophoresis of genomic DNA and/or nucleic acid sequencing of $16 \mathrm{~S}$ ribosomal DNA. ${ }^{13}$ We wondered whether strain differences correlated with disease states. None of these strains were identical using these techniques.

We observed, by transmission electron microscopy, that internalised $H$ pylori were more often coccoid in appearance in contrast to adherent or non-adherent $H$ pylori, which were more often bacilliform in appearance. These differences, which have been observed by others, might be artefactual and related to cross-sectioning of the bacilliform, spiral shaped $H$ pylori organisms by the transmission electron microscopy technique. ${ }^{89}$ However, if these differences are true, it may be that coccoid forms of the organism reflect degenerative alterations or adaptations to marginal or hostile environments with the capacity for regrowth. ${ }^{8} 9$

The efficient penetration of HEp-2 cells by nearly all of the $H$ pylori strains that we evaluated could explain, in part, the difficulties that have been encountered in eradicating $H$ pylori organisms in human infections. Specifically, if antimicrobials that do not permeate gastric or duodenal mucosal cells are used, then internalised $H$ pylori organisms might be unaffected. ${ }^{25}$ In this regard, the acridine orange
A

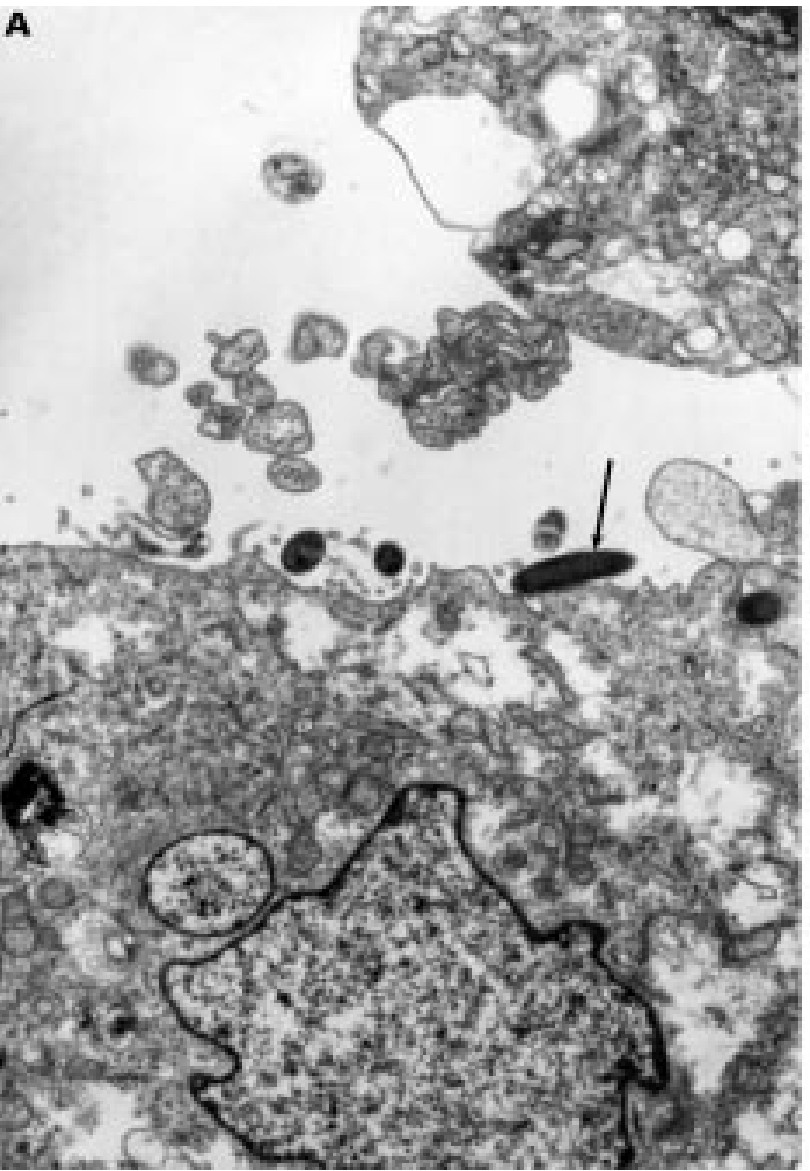

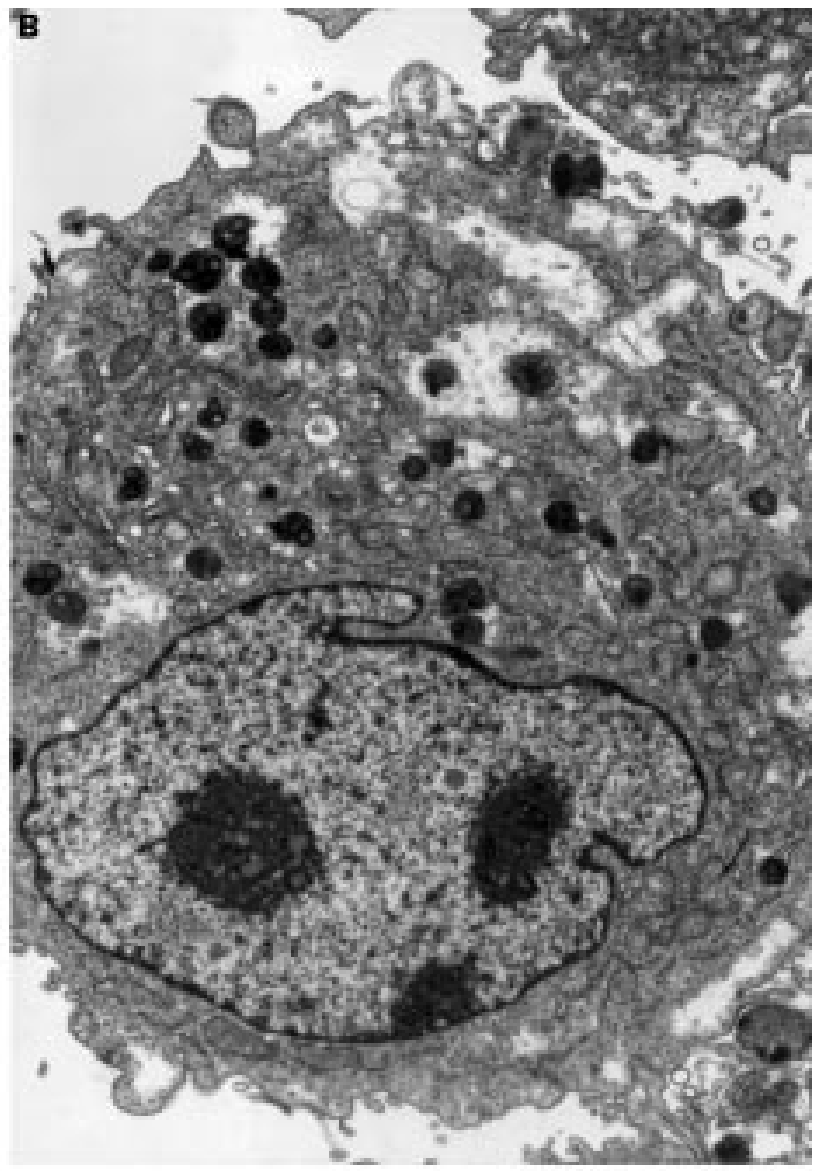

Figure 2 Representative thin section transmission electron photomicrographs. (A) Helicobacter pylori ATCC 51652 (aka MC903); note the closely adhering bacilliform bacterium (arrow). (B) Helicobacter pylori ATCC 51652; note the numerous internalised bacteria, which are more coccoid than bacilliform in appearance. Also present are cytoplasmic vacuoles in close proximity to some internalised bacteria, which are most likely the result of the vacuolating cytotoxin produced by H pylori organisms. 
assay might be useful for assessing the ability of newer antimicrobials, alone or in combination, to kill $H$ pylori which adhere to or penetrate mammalian cells.

An incidental in vivo finding of our study was that for many patients the endoscopic appearance of the gastric mucosa was relatively normal, yet histological inspection of random biopsies showed moderate to severe gastritis (table 1). Also, in many cases, special staining of tissue sections also showed high or moderate numbers of $H$ pylori organisms, despite an unremarkable gross appearance of the gastric tissue. These observations emphasise the importance of obtaining random gastric biopsies for histopathogenic evaluation in patients with dyspepsia. Alternatively, other sensitive methods for diagnosing $H$ pylori infection, including rapid urease testing of biopsied tissue or the detection of $H$ pylori urease production by non-invasive methods (such as isotopic carbon urea breath testing), should be considered. ${ }^{26}$

In conclusion, by using the acridine orange assay, we were able to determine that the intracellular infection frequencies of HEp-2 cells by clinical strains of $H$ pylori were significant, often equalling that of the $Y$ enterocolitica strain that we also studied. Furthermore, internalised $H$ pylori seemed viable for up to six hours. Co-incubation of bacteria and HEp-2 cells beyond six hours was difficult owing to significant HEp-2 cytotoxicity. These results require further study, but may have important implications for treatment and prevention strategies for this important upper tract enteric pathogen. The acridine orange assay may also be useful for assessing, in vitro, the effects of antimicrobials, alone or in combination, to kill intracellular $H$ pylori organisms.

We thank Roberta Kondert for help in preparing the manuscript.

1 Evans DG, Evans DJ, Graham DY. Adherence and internalization of Helicobacter pylori by HEp-2 cells. Gasinternalization of Helicobacter pylo

2 Wyle FA, Tarrawski A, Schulman D, et al. Evidence for gastric cell invasion by C. pylori, an ultrastructural study. $\mathcal{F}$ tric cell invasion by C. pylori, an ultrastruct
Clin Gastroenterol 1990;12(suppl 1):S92-8.

3 Andersen LP, Dessi A, Usai P. Morphological study of the gastric antral mucosa colonized by Campylobacter pylori Ital f Gastroenterol 1990;22:22-3.

4 Bale G, Malfertheiner P, Ditschuneit H. Invasion of Campylobacter-like organisms in the duodenal mucosa in patients with active duocenal ulcer. Klin Wochenshr 1987;65:144-6.
5 Kazi JL, Sinniah R, Zaman V, et al. Ultrastructural study of Helicobacter pylori-associated gastritis. F Pathol 1990;161: Helicobac.

6 Tricollet V, Bruneval P, Vire O, et al. Campylobacter-like organisms and surface epithelium abnormalities in active, chronic gastritis in humans: an ultrastructural study. Ultrastruct Pathol 1986;10:113-22.

7 Lee WK, Gourley WK, Buck GE, et al. A light and electron microscopic study of a Campylobacter-like bacteria inhabiting the human stomach. Gastroenterology 1985;88:1470.

8 Noach LA, Rolf M, Tytgat GN. Electron microscopic study of association between Helicobacter pylori and gastric and duodenal mucosa. I Clin Pathol 1994;47:699-704.

9 Bode G, Malfertheiner P, Ditschuneit H. Pathogenetic implications of ultrastructural findings in Campylobacter pylori related gastroduodenal disease. Scand f Gastroenterol 1990;23(suppl 142):25-39.

10 Miliotis MD. Acridine orange stain for determining intracellular enteropathogens in $\mathrm{HeLa}$ cells. $f$ Clin Microbiol 1991;29:830-1.

11 West SS. Quantitative microscopy in bacteriology. Ann NY Acad Sci 1969;157:111-22.

12 Goldner M, Farkas-Himsley H, Kormendy A, et al. Bacterial phagocytosis monitored by fluorescence and extracellular quenching: ingestion and intracellular killing. Lab Med 1983;14:291-4.

13 Eckloff BW, Podzorski RP, Kline BC, et al. A comparison of $16 \mathrm{~S}$ ribosomal DNA sequences from five isolates of Helicobacter pylori. Int $\mathcal{F}$ Syst Bacteriol 1994;44:320-3.

14 Vaudaux P, Waldvogel FA. Gentamicin antibacterial activity in the presence of human PMNs. Antimicrob Agents Chemother 1979;16:743-9.

15 McDowell EM, Trump BF. Histologic fixatives suitable for diagnostic light and electron microscopy. Arch Pathol Lab Med 1976;100:405-14.

16 Spurr AR. A low-viscosity epoxy resin embedding medium for electron microscopy. F Ultrastruct Res 1969;26:31-43.

17 Bovallius A, Nilsson G. Ingestion and survival of Y. pseudotuberculosis in HeLa cells. Can f Microbiol 1975;21:19772007.

18 Devenish JA, Schiemann DA. HeLa cell infection by Yersinia enterocolitica: evidence for lack of intracellular multiplication and development of a new procedure for multiplication and development of a new procedure for quantitativ 45 .

19 Sansonetti PJ, Ryter A, Cleve P, et al. Multiplication of Shigella flexneri within HeLa cells: lysis of the phagocytic vacuole and plasmid-mediated contact hemolysis. Infect Immun 1986;51:461-9.

20 Leunk RD, Johnson PT, David BC, et al. Cytotoxic activity in broth culture filtrate of Campylobacter pylori. $\mathcal{F} \mathrm{Med}$ Microbiol 1988;26:93-9.

21 Cover TL, Blaser MJ. Purification and characterization of the vacuolating toxin from Helicobacter pylori. $7 \mathrm{Biol} \mathrm{Chem}$ 1992;267:10570-5.

22 Crabtree JE, Figura N, Taylor JD, et al. Expression of a 120 kilodalton protein and cytotoxicity in Helicobacter pylori. $\mathcal{F}$ Clin Microbiol 1992;45:733-4.

23 Small PLC, Iseberg RP, Falkow S. Comparison of the ability of enteroinvasive Escherichia coli, Salmonella typhimurium, Yersinia pseudotuberculosis and Yersinia enterocolitica to enter and replicate within HEp-2 cells. Infect Immun 1987;55:1674-9.

24 Evans DG, Karjalainen TK, Evans DJ, et al. Cloning, nucleotide sequence, and expression of a gene encoding an adhesin subunit protein of Helicobacter pylori. $\mathcal{F}$ Bacteriol 1993;175:674-83.

25 Andersen LP, Nielsen H, Norgaard A, et al. Intracellular survival of Helicobacter pylori and susceptibility of these bacteria to antibiotics. 93rd general meeting of the American Society for Microbiology, Atlanta, Georgia, 1993.

26 Cutler AF, Havstad S, Ma K, et al. Accuracy of invasive and noninvasive tests to diagnose Helicobacter pylori infection. Gastroenterology 1995;109:136-41. 